\title{
The Effects of Maternal Childhood Attachment and Paternal Involvement in Child-Rearing and Maternal Parenting Efficacy on Parenting Behavior of Mothers with Infants
}

\author{
Hye-Jin $\mathrm{Oh}^{1}$, Hyun-Sim Doh ${ }^{2}$ \\ Adjunct Professor, Department of Child Development \& Intervention, Ewha Womans University, Seoul, Korea ${ }^{1}$ \\ Professor, Department of Child Development \& Intervention, Ewha Womans University, Seoul, Korea ${ }^{2}$ \\ 영아기 자녀를 둔 어머니의 아동기 애착 및 아버지의 양육참여와 어머니의 \\ 양육효능감이 양육행동에 미치는 영향 \\ 오혜진 ${ }^{1}$ 도현심 ${ }^{2}$ \\ 이화여자대학교 아동학과 겸임교수 ${ }^{1}$, 이화여자대학교 아동학과 교수 ${ }^{2}$
}

\begin{abstract}
Objectives: The main purpose of this study was to examine direct effects of maternal childhood attachment and paternal involvement on parenting behavior, and indirect effects through maternal parenting efficacy.

Methods: A total of 310 participants, mothers of 6-to 15 -month-old infants, responded to questionnaires, which included items related to maternal childhood attachment, paternal involvement, maternal parenting efficacy, and parenting behavior. Data were analyzed by using structural equation modeling (SEM).

Results: The major findings of the study were summarized as follows: First, maternal childhood attachment and paternal involvement had direct effects on maternal parenting behavior. Second, maternal childhood attachment and paternal involvement had indirect effects on parenting behavior through maternal parenting efficacy.

Conclusions: This study reveals the importance of maternal childhood attachment and paternal involvement, and maternal parenting efficacy in increasing maternal sensitivity and positive parenting behaviors. It emphasizes the relative effects of maternal parenting efficacy on parenting behavior. The results of this study offer the foundation in designing parenting education programs for parents with infants in order to enhance maternal parenting behavior.
\end{abstract}

Keywords: maternal childhood attachment, paternal involvement, parenting efficacy, parenting behavior

\section{Introduction}

영아기는 신체, 인지, 사회·정서 발달이 급속도로 이루어지는 시기로(Snow, 1989), 이 시기의 부모역할은 다른 어느 시기보

Corresponding Author: Hyun-Sim Doh, Professor, Department of Child Development \& Intervention, Ewha Womans University, 52, Ewhayeodaegil, Seodaemun-gu, Seoul, Korea

E-mail: simdoh@ewha.ac.kr
다 매우 중요하다. 영아기의 부모는 기본적인 신뢰 형성의 기 반으로서의 역할, 양육자로서의 역할, 발달적 상호작용자로서 의 역할, 다양한 물질적 자극을 제공하고 발달을 촉진하는 등 다양한 역할들을 수행한다(Berk \& Meyers, 2002). 이러한 점에 (c)The Korean Association of Child Studies

This is an Open Access article distributed under the terms of the Creative Commons Attribution Non-Commercial License (http:// creativecommons.org/licenses/by-nc/4.0) which permits unrestricted noncommercial use, distribution, and reproduction in any medium, provided the original work is properly cited. 
서 많은 선행 연구들은 선천적인 유전적 요인뿐만 아니라 부 모가 자녀에게 제공하는 양육환경을 영아의 발달에 중요한 영 향을 미치는 요인으로 주목하면서 부모 양육행동의 중요성을 강조하고 있다. 특히, 영아는 어머니와의 상호작용을 통해서 건강한 관계들을 발전시키고 정서조절, 사회적 유능성과 같 은 기술들을 발달시킨다(Braungart-Rieker, Garwood, Powers, \& Notaro, 1998). 영아의 발달 과정에서 주 양육자인 어머니와 영 아 간에 형성되는 긍정적 관계는 영아의 이후의 성장 발달 및 성격 형성에 중요한 영향을 미친다.

영아기 부모의 행동은 주로 민감성(sensitivity)과 반응성 (reactivity)에 의해 이끌어지며, 특히 영아의 정서적 신호에 대 한 어머니의 차별화된 민감성은 아동의 사회·정서적 기능과 밀접하게 관련된다(Belsky, 1984; Bornstein \& Tamis-LeMonda, 1989). 또한, 주 양육자로서 어머니가 영아에게 자극을 제공하 고 가르치는 양육행동은 다양한 영역에서 영아의 긍정적 발달 을 촉진하고(Bornstein \& Tamis-LeMonda, 1989), 제한설정 양 육행동은 규칙 준수를 통해 환경을 구조화시키는 것을 의미하 는 것으로 구조화되지 않은 양육환경은 영아의 부정적 발달과 관련되는 것으로 보고된다(Chamberlain \& Patterson, 1995). 그 러므로 발달의 토대를 마련하는 영아기는 다른 어느 시기보다 영아의 필요와 요구에 대한 어머니의 민감성과 물질적인 자극 을 제공하고 가르치는 양육, 제한설정 양육행동 등과 같은 긍 정적 양육행동이 중요한 시기이다.

어머니의 긍정적 양육행동은 특히, 아동의 애착 안정성 을 형성하는 데 매우 중요한 요인임에도 불구하고(Ainsworth, Blehar, Waters, \& Wall, 1978), 최근 10여년 동안 영아를 대상으 로 한 국내 연구는 지속적으로 이루어졌으나, 6-15개월의 영 아들에 관한 연구는 방법론적 한계로 연구가 활발히 수행되지 못하였다. 국내외 연구 모두 어머니의 양육행동을 측정하기 위해 질문지법과 실험, 관찰법을 보편적으로 사용하였으나 실 험, 관찰법은 대상 섭외, 시간과 비용 등 연구 진행 측면의 어 려움이 있고(G. H. Kim \& Hong, 2013), 영아기 자녀를 둔 어 머니의 민감한 양육행동에 관한 척도 개발 연구 또한 불충분 하여, 몇몇 연구들(J.-Y. Lee, 2009; S. Y. Park, 2013; Seo \& Lee, 2014)을 제외하고는 특히, 6-15개월 영아기 자녀를 둔 어머니 의 민감한 양육행동과 관련된 국내 연구는 부족한 실정이다. 따라서 영아기 자녀를 둔 어머니의 양육행동과 관련 변인들 간의 관계에 관한 학문적 관심이 제기된다.

어머니의 양육행동과 관련 변인들 간의 관계는 Belsky (1984)의 자녀양육 과정 모델(determinants of parenting: a process model)에 근거하여 접근할 수 있다. Belsky의 자녀양
육 과정 모델은 부모 개인의 발달역사와 양육 간의 관계를 밝 히고 있다. 유년시절 부모로부터 분리되는 스트레스 경험은 정서적 장애의 위험요인이 될 뿐만 아니라(Brown \& Harris, 1978), 어린 자녀들을 양육하는 과정의 어려움들과 관련된다 (Frommer \& O'Shea, 1973). 또한, 아동학대에 관한 논문들을 살펴보면, 부모 자신의 유년시절 학대 경험과 자신의 자녀에 대한 학대 간의 관련성을 강조한다(Belsky, 1980).

또한, Belsky는 부모의 양육행동을 촉진시키거나 약화시키 는 지지와 스트레스의 세 가지 원천으로 부부관계, 사회적 관 계망, 직업을 강조한다. 선행 연구들(Harris \& Morgan, 1991; McBride \& Mills, 1993)에 근거할 때, 부부관계의 질은 자녀양 육에 대한 아버지의 참여 수준에 중요한 역할을 한다. 4 개월의 영아를 둔 만삭과 초산의 105 명의 어머니들을 대상으로 한 연 구에서(Crnic, Greenberg, Ragozin, Robinson, \& Basham, 1983), 배우자의 양육참여를 통한 지지가 어머니의 양육태도에 가장 긍정적인 영향을 미치는 것으로 보고된다.

이와 관련하여, 선행 국내외 연구들은 부모의 양육행동에 영향을 미치는 선행 요인으로 아동의 특성으로서의 기질을 포 함하여(M. J. Kim \& Lee, 2011), 개인적 특성인 어머니의 원가 족과의 관계(Brown, Larson, Harper, \& Holman, 2016; Kwahk $\& \mathrm{Kim}, 2006)$, 인지적 특성인 양육효능감(Kohlhoff \& Barnett, 2013; Pereira et al., 2012), 정서적 특성인 양육스트레스(Yoon $\&$ Cho, 2011), 가족구성원 간의 관계(McHale \& Lindahl, 2011) 의 측면인 부부관계(Crnic et al., 1983) 및 아버지의 역할(Ruiz, Carrasco, \& Holgado-Tello, 2016; Seo \& Lee, 2014) 등을 제안하 고 있다. 이러한 다양한 요인들 가운데 부모와 관련된 요인들 은 부모 자신의 양육행동은 물론 아동의 발달결과에 영향을 미치는 요인으로서 지속적으로 강조되고 있다. 어머니의 양육 행동에 초점을 둘 때, 특히 어머니의 발달역사를 비롯해서 개 인적 특성과 배우자의 역할 등은 중요한 요인으로 가정할 수 있다.

개인의 발달역사와 관련하여, 국내외 연구자들은 어머니 의 아동기 애착 요인들에 주목하면서 어머니의 아동기 애착과 양육행동 간의 관계의 중요성을 강조하였다(Biringen, 1990; Eiden, Teti \& Corns, 1995; Kwahk \& Kim, 2006). Biringen (1990) 에 따르면, 유년시절에 자신의 부모로부터 수용적 감정을 보 고했던 어머니들은 부모에 의해 수용되지 못한 감정을 보고했 던 어머니들에 비해서 그들의 영아들을 더 민감하고 반응적으 로 양육하는 것으로 보고된다. 또한, 영아기 자녀를 둔 어머니 를 대상으로 한 연구(Eiden et al., 1995)에서 어머니의 아동기 애착이 안정애착일 경우 어머니의 민감성이 높고 자녀와의 상 
호작용이 긍정적이었다. 다시 말해서, 안정적인 내적 실행모 델(internal working model)을 지닌 어머니들은 더 민감한 긍정 적인 양육행동을 수행하게 된다(Bowlby, 1969).

앞서 서술한 어머니의 개인적 특성인 아동기 애착 외에도, 어머니의 인지적 요인로서의 양육효능감은 어머니의 양육 행동의 선행 요인으로 잘 알려져 있다. 양육효능감(parenting efficacy)은 자녀를 양육하는 데 관련된 업무들을 조직화하고 수행할 수 있는 부모로서의 능력에 대해 부모가 가지는 신념 으로 정의된다(Kohlhoff \& Barnett, 2013). 어머니의 양육효 능감과 양육행동 간의 관계에 관한 국내외 선행 연구들을 살 펴보면, 양육효능감이 높은 부모들은 자녀양육 시 더 민감하 고 반응적이며 더 다양한 자극을 제공할 뿐만 아니라 자녀들 과 더 많은 상호작용을 하는 것으로 보고된다(Crockenberg \& Smith, 2002; J.-Y. Lee, 2009; Yoon \& Cho, 2011). 또한, 부모 스 스로 양육효능감을 높게 지각할수록 문제 상황에서 자녀에 게 적합한 해결방법을 제시하고, 일관된, 온정적, 수용적인 양 육행동을 더 많이 보이고 자율적인 격려를 많이 하는 반면(H. M. Kim \& Doh, 2004), 양육효능감이 낮은 경우, 자녀에게 통 제적인 양육행동을 더 많이 보이는 것으로 보고된다(Coleman $\&$ Karraker, 1997). 어머니의 양육효능감, 양육스트레스, 반응 적인 부모의 양육행동 간의 관계를 구조방정식을 이용하여 살 펴본 연구(Yoon \& Cho, 2011)에서 양육효능감은 어머니의 양 육행동을 가장 잘 설명하는 예측변수로 나타났으며, 양육효능 감은 양육스트레스와 반응적인 부모의 양육행동 간의 부적인 관계를 매개하고 있음이 발견되었다.

한편, 영아기는 어버이로서 부부의 변화가 이루어지는 시 기로 연구자들은 부부관계(Crnic et al., 1983), 부모 개인과 자 녀와의 관계(Bandura \& Walters, 1959), 자녀와 관련된 문제에 대한 부부 사이의 의사소통(Belsky, 1982), 아버지의 양육참여 를 통한 부모공동양육 관계(Seo \& Lee, 2014) 등에 초점을 두 고 있다. 특히, 영아기의 어머니 역할을 강조한 선행 연구들은 어머니의 양육행동에 영향을 미치는 부부관계의 요인으로 아 버지의 역할에 관심을 기울여 왔다. 1990년대 이후 아버지의 역할과 현대적인 아버지 상에 대한 관심이 고조되기 시작하면 서(Marsiglio, Amato, Day, \& Lamb, 2000), 아버지에게 진정한 양육을 분담하는 공동양육자(true coparents)로서의 역할을 수 행할 것에 대한 요구가 증가하였다(Pleck \& Pleck, 1997). 이러 한 시대적 흐름에 따라 최근 아버지의 역할에 대한 인식이 변 화하면서 많은 국내외 선행 연구들(Ruiz et al., 2016; Seo \& Lee, 2014)은 아버지의 양육참여가 갖는 긍정적 효과를 강조하고 있다.
무엇보다도, 영아기 동안 아버지의 직접적 양육참여는 궁극적으로 아동의 발달에 긍정적 영향을 미친다는 점에서 (Allen \& Daly, 2007) 더욱 더 주목할 필요가 있다. 영아를 목욕 시키고 우유나 간식을 먹이고 영아와 이야기하고 놀아주기 등 아버지의 도구적 도움을 통한 양육참여는 양육에 지친 어머니 를 돕고 양육부담을 덜어줌으로써 어머니에게 정서적 지지를 제공하여, 어머니의 양육행동에 긍정적 영향을 미칠 것으로 예상할 수 있다. 그러나 아버지의 직접적 양육참여가 영아기 자녀를 둔 어머니의 양육행동에 미치는 영향을 살펴본 국내 외 선행 연구(Allen \& Daly, 2007; Belsky, 1982; S. H. Kim, 1998; Seo \& Lee, 2014)는 매우 부족한 편이다. 이와 관련하여, 몇몇 국내외 연구들은 아버지의 양육참여가 많을 경우, 어머니의 온정적, 민감하고 반응적인 양육행동이 많다고 보고하고 있다 (Seo \& Lee, 2014). 또한, Belsky (1982)의 연구에서도 영아기의 어머니 역할(mothering)에 있어서 남편들의 지지와 긍정적인 관심의 긍정적 영향력을 포함하며, $1,3,9,15$ 개월에 아버지의 양육참여와 부부 간의 의사소통 간의 밀접한 관련성을 보고하 였다(Belsky, 1979). 따라서 본 연구에서는 영아기 자녀를 둔 어 머니의 양육행동의 선행 변인으로서 아버지의 양육참여의 영 향력을 확인하고자 하였다.

이와 같이, 어머니의 아동기 애착 및 양육효능감과 아버지 의 양육참여는 영아기 자녀를 둔 어머니의 양육행동에 각각 영향을 미치는 주요한 선행 변인들이며, 동시에 어머니의 아 동기 애착과 아버지의 양육참여는 어머니의 양육효능감과 밀 접한 관련이 있음이 보고되고 있다. 어머니의 아동기 애착과 양육효능감 간의 관계와 관련하여, 이를 살펴본 국내외 연구 는 아버지의 양육참여와 어머니의 양육효능감 간의 관계에 대한 연구들에 비해 매우 드물긴 하나, Leerkes와 Crockenberg (2002)는 원가족에서의 유년시절 경험이 자녀양육 과정에 서 어머니의 자신감과 관련됨을 보고하였다. 92 명의 초산 의 어머니들과 생후 6개월 된 영아들에 관한 연구(Leerkes \& Crockenberg, 2002)에서, 양육효능감은 전반적인 자존감의 중 재효과를 통해서 기억하고 있는 어머니의 돌봄, 유년시절 경 험에 의해 예측됐다. 즉, 유년시절에 부모로부터 정서적 요 구가 충족되었던 어머니들은 성인이 되어 안정 애착을 형성 하고 높은 자기효능감을 보고한 반면, 유년시절에 부모로부 터 정서적 거부를 많이 경험했던 어머니들은 성인이 되어 불 안정 애착을 형성하고 낮은 정서적 효능감을 보고하였다. 76 명의 학대 경험이 있는 어머니들에 관한 연구에서는 유년시 절 학대는 불안정 애착과 어머니의 우울을 포함하는 경로들을 중재함으로써 양육효능감을 예측했다(Caldwell, Shaver, Li, \& 
Minzenberg, 2011).

어머니의 아동기 애착과 마찬가지로, 아버지의 양육참여 또한 어머니의 양육효능감과 관련되어, 자녀양육 과정에서 아 버지의 양육참여를 통해 이루어지는 실질적 도움은 어머니의 양육효능감의 주요한 예측 변인으로 간주되어 왔다(Belsky \& Vondra, 1989; Cochran \& Niego, 1995; E. Kim \& Jeon, 2016). 아버지의 양육참여는 자녀양육으로 인한 어머니의 스트레스 를 직접적으로 경감시킬 뿐 아니라 정서적 지지를 통해 간접 적으로 어머니의 양육효능감을 높일 수 있다(Belsky \& Vondra, 1989). 미국에서 수행된 연구(Cochran \& Niego, 1995)에 의 하면, 배우자의 양육참여를 통해 충분한 지지를 받은 여성들 은 지지가 부족한 여성들에 비해 더 높은 양육효능감을 나타 내었다. 이러한 결과는 국내 연구들(Choe \& Chung, 2005; E.

$\operatorname{Kim} \&$ Jeon, 2016)에서도 일관되게 보고되고 있다. 맞벌이 부모 간 아버지의 양육참여의 지각 차이와 부부갈등 간의 관계 를 살펴본 연구에 의하면, 어머니가 아버지의 양육참여 수준 을 높게 지각할수록 어머니의 자기효능감이 높았고(E. Kim \& Jeon, 2016), 관계적 요인들과 사회적 지원 간의 관계를 살펴본 연구(Choe \& Chung, 2005)에서 일관된 배우자의 협력이 다른 사람들의 지원보다 양육효능감에 더 많은 영향을 미치는 것으 로 보고된다.

종합해보면, 영아기 자녀를 둔 어머니의 양육행동은 어머 니의 개인적·인지적 변인, 공동양육자인 아버지 변인들이 복 합적으로 관련되어 있다. 개인적 특성인 어머니의 아동기 애 착과 가족관계적 특성인 아버지의 양육참여, 인지적 특성인 어머니의 양육효능감이 영아기 자녀를 둔 어머니의 양육행동 에 미치는 영향을 비롯하여 그 선행 변인들 간의 밀접한 관련 성에 근거할 때, 이러한 변인들 간의 경로를 예측할 수 있다. 즉, 어머니의 아동기 애착과 아버지의 양육참여는 각각 어머 니의 양육행동에 직접적 영향을 미칠 뿐 아니라 어머니의 양 육효능감에 영향을 미치고 이는 어머니의 양육행동에 간접 적 영향을 미치리라 가정된다. 그러나 선행 국내 외 연구들은 대부분 각 변인 간의 단편적 관계나 일부 변인들 간의 경로(Y. J. Chyung, 2008; Kohlhoff \& Barnett, 2013; Suzuki, Holloway, Yamamoto, \& Mindnich, 2009; Yoon \& Cho, 2011)를 살펴보는 데 그쳐, 어머니의 개인적 특성, 관계적 특성 및 인지적 특성을 모두 고려하여 어머니의 양육행동에 미치는 과정과 경로를 살 펴본 연구는 매우 드물다. 자녀의 발달단계 또한 걸음마기와 유아기에 초점을 맞추고 있어, 영아기 자녀를 둔 어머니를 대 상으로 이러한 경로를 살펴본 연구는 거의 발견하기 어렵다.

따라서 본 연구는 선행 연구들에 근거하여 어머니의 아동
기 애착 및 아버지의 양육참여와 어머니의 양육효능감이 어머 니의 양육행동에 영향을 미치는 경로를 탐색함으로써, 어머니 의 아동기 애착 및 아버지의 양육참여가 어머니의 양육행동에 미치는 직접적 영향과 어머니의 양육효능감을 통한 간접적 영 향을 살펴보았다.

본 연구에서 선정한 연구문제는 다음과 같다.

\section{연구문제 1}

영아기 자녀를 둔 어머니의 아동기 애착 및 아버지의 양육참 여와 어머니의 양육 효능감은 어머니의 양육행동에 어떠한 경로로 영향을 미치는가?

1-1 영아기 자녀를 둔 어머니의 아동기 애착 및 아버지의 양 육참여는 어머니의 양육행동에 직접적 영향을 미치는가?

1-2 영아기 자녀를 둔 어머니의 아동기 애착 및 아버지의 양육참여는 어머니의 양육효능감을 통해 어머니의 양육행 동에 간접적 영향을 미치는가?

\section{Methods}

\section{연구대상}

본 연구의 참가자는 전국의 6-15개월 영아기 자녀를 둔 310명 의 전업 주부들이다. 영아기의 정서적 신호에 대한 어머니의 민감성과 효과적으로 반응하는 능력은 아동의 안정 애착 형 성에 중요하고 영아기의 안정 애착은 인지, 언어 및 사회·정 서 발달과 관련하여 중요하다는 연구결과들(Belsky, 1984; Braungart-Rieker et al., 1998; Pearson et al., 2011)에 근거하여 애 착 형성의 주요한 시기인 6-15개월 영아기 자녀를 둔 어머니 들을 연구대상으로 선정하였다.

연구 참가자의 사회 인구학적 특성을 살펴보면, 거주 지 역은 서울 및 수도권 179명(57.8\%), 경상도 75명(24.1\%), 충 청도 29명(9.3\%), 전라도 24명(7.7\%), 강원도 2명(0.6\%), 제 주도 1 명 $(0.3 \%)$ 순이었다. 영아의 성별 구성은 남아 157 명 (50.6\%), 여아 153명(49.4\%)으로 유사한 성비를 보였다. 영아 의 평균 월령은 10.5 개월 $(S D=2.68)$ 이었다. 출생순위의 경우, 첫째가 104 명 $(33.5 \%)$ 로 가장 많았으며, 그 다음으로 둘째 95 명(30.6\%), 외동아 75명(24.2\%), 셋째 33명(10.6\%), 기타 3명 $(0.9 \%)$ 순이었다. 아버지의 연령은 36-40세가 156 명(50.3\%)으 
로 가장 많았고, 그 다음으로 31-35세 88명(28.4\%), 41-45세 37 명(11.9\%), 26-30세 20명(6.5\%), 46세 이상 5명(1.6\%), 20-25 세 4 명 $(1.3 \%)$ 순이었다. 어머니의 연령은 $31-35$ 세가 145 명 (46.8\%)으로 가장 많았고, 그 다음으로 36-40세 79명(25.5\%), 26-30세 68명(21.9\%), 20-25세 9명(2.9\%), 41세-45세 9명 (2.9\%) 순이었다. 부모의 교육수준의 경우, 대학교를 졸업한 경우가 아버지와 어머니 각각 170 명(54.8\%)과 175명(56.5\%) 으로 가장 많았다. 아버지의 직업은 회사원, 은행원, 공무원, 교사 129명(41.6\%), 전문직 60명(19.4\%), 일반 사무직, 보안 업무 38명(12.3\%), 자영업 30명(9.7\%), 생산직 감독, 서비스직 29 명(9.4\%), 기타 19 명(6.2\%) 순이었다.

\section{연구도구}

본 연구의 조사도구는 어머니의 아동기 애착, 아버지의 양육 참여, 어머니의 양육효능감 및 어머니의 양육행동을 측정하기 위한 척도로 구성되어 있으며, 모든 척도는 어머니에 의해 보 고되었다. 각 문항은 거의 그렇지 않다(1점), 그렇지 않은 편이 다(2점), 그런 편이다(3점), 매우 그렇다(4점)의 Likert식 4점 척 도로 구성되며, 점수가 높을수록 각 변인의 특성이 높음을 나 타낸다.

\section{어머니의 아동기 애착}

어머니의 아동기 애착은 Hazan과 Shaver (1992)의 성인애착 척 도(Adult Attachment Scale [AAS])를 H.-J. Jeon (1994)이 번역하 고 Kwahk \& Kim (2006)이 수정한 척도를 사용하여 측정하였 다. 이 척도는 어머니가 자신의 아동기(5-12세 정도) 부모와 의 관계에 대해 회상하는 내용으로 구성되어 있으며, 어머니 의 애착에 관한 반 구조화된 면접평가도구인 Adult Attachment Interview (AAI)를 근거로(George, Kaplan, \& Main, 1985) 어머 니가 기억해낼 수 있는 가장 어린 시절로 돌아가서 아버지와 의 관계와 어머니와의 관계에 대해 응답하도록 되어 있다(각 16 문항, 총 32 문항). 문항의 예로는 "나는 아버지/어머니와 자 연스럽게 가까워질 수 있었다.”, "나는 아버지/어머니가 진정 으로 믿고 의지할 만하다고 느껴지지 않았다.” 등이 포함된다. 부정적 의미의 문항을 역채점한 뒤 점수가 높을수록 어머니가 아동기에 자신의 원가족 부모와 형성한 애착의 안정성이 높은 것을 의미한다. 문항 간 신뢰도(Cronbach's $\alpha$ )는 아버지 애착 과 어머니 애착이 각각 .87 이었고 전체 신뢰도는 . 90 이었다.

\section{아버지의 양육참여}

아버지의 양육참여는 Nugent (1991)의 아버지의 양육참여 척 도(The Father Caretaking Inventory [FCI])를 S. H. Kim (1998)이 수정·보완한 것을 사용하여 측정하였다(11문항). 문항의 예 로는 "아이와 이야기하거나 함께 놀아준다.", "밤에 자다가 아 이가 울면 달래준다.” 등이 포함된다. 이 척도의 전체 신뢰도 (Cronbach's $\alpha$ )는 .91이었다.

$$
\text { 어머니의 양육효능감 }
$$

어머니의 양육효능감은 Gibaud-Wallston과 Wandersman (1978) 의 양육효능감 척도(Parenting Sense of Competence [PSOC])를 M. J. Kim (2008)이 수정·번안한 척도를 사용하여 측정하였다. 이 척도는 인지적 측면인 부모효능감(8문항)과 정서적 측면 인 부모로서의 불안감( 9 문항)의 2 개 하위요인으로 구성되어 있다(총 17문항). 문항의 예로는, 부모효능감의 경우 “좋은 어 머니가 되는 것은 그 자체로서 의미가 있다.", "나는 우리 아이 를 힘들게 하는 것이 무엇인지 알고 있다.” 등이, 부모로서의 불안감의 경우 “부모라는 역할 때문에 나는 긴장되고 불안하 다.", "부모로서 어려움을 느낄 때는 내가 현재 잘하고 있는지 에 대한 확신이 없을 때이다.” 등이 포함된다. 문항 간 신뢰도 (Cronbach's $\alpha$ )는 부모효능감 .75, 부모로서의 불안감 .77이었 고, 전체 신뢰도는 .75이었다

\section{어머니의 양육행동}

어머니의 양육행동은 Bornstein (1989)의 양육유형(The Parental Style Questionnaire [PSQ]) 척도를 H. M. Lee, Park과 Seo (2008) 가 수정·번안한 척도와, Pederson 등(1990)이 개발한 어머니 행동(Maternal Behavior Q-set [MBQ]) 척도를 E. S. Kim (2013) 이 수정·번안한 어머니의 민감성 척도를 축약하여 사용하 였다. H. M. Lee 등(2008)의 척도는 사회적 상호작용(social interaction)(6문항), 가르치는/물질적 자극(didactic/material stimulation) 양육(5문항), 제한설정(limit setting) 양육(2문항) 등 세 가지 하위요인(총 13문항)으로 구성되어 있으나, 사회적 상 호작용 요인은 E. S. Kim (2013)의 민감성 척도와 중복된다는 4 명의 아동학 전공 교수들의 평가에 따라 제외하였다.

민감성 척도와 관련하여, Pederson 등(1990)의 MBQ는 영아 에 대한 어머니의 반응을 요구하는 상황에서 어머니의 민감하 고 반응적인 행동을 묘사한 90 개의 문항(9점 척도)로 구성되 
어 있으나, E. S. Kim (2013)은 원척도에서 어머니의 민감성 정 도의 준거 점수 7.0 이상인 31 문항을 5점 척도로 간편화하여 사용하였다. 본 연구에서는 31 문항의 적절성을 확인하기 위 해 문항의 대표성에 대한 내용타당도 검증을 실시하였다. 내 용타당도는 Lynn (1986)이 제시한 내용타당도 지수(Content Validity Index [CVI])를 이용하여 전문가 집단을 4인의 아동학 전공 교수들로 구성하여 검증하였다. 내용타당도는 매우 타당 함(4점), 타당함(3점), 타당하지 않음(2점), 전혀 타당하지 않음 (1점)과 같이 4점 척도로 평가한 뒤, 각 문항에 대한 전문가 집 단의 평점 결과가 3점과 4점으로 평가된 문항을 전문가수로 나누어 비율로 계산하였다. 최종적으로 CVI가 .80 이상인 총 19 문항을 선정하였다. 채택된 19문항은 .80 1.00의 내용타 당도를 보였고, 나머지 12 문항은 모두 . 50 의 내용타당도를 보 였다. 최종적으로, 본 연구의 어머니의 양육행동 척도는 가르 치는/물질적 자극 양육(5문항), 제한설정 양육(2문항), 민감성 (19문항) 등 3 개 하위요인(총 26문항)으로 구성되었다.

각 하위요인의 문항의 예를 들면 다음과 같다. 가르치는/물 질적 자극 양육은 "나는 내 아이에게 물건, 사건, 활동들의 이 름, 내용을 설명해주고 책을 읽어주는 등 언어 학습의 기회를 마련해준다.” "나는 내 아이에게 필요한 환경을 계획해서 마 련해 준다." 등이, 제한설정 양육은 "나는 내 아이에게 규칙 지 키기와 예의를 강조해서 가르친다.", "나는 내 아이에게 권위 를 존중하도록 엄격한 규칙을 가지고 가르친다.” 등이, 그리 고 민감성은 "아이가 미소 짓고 부를 때 신속하게 알아차린 다.", "아이의 반응을 보면서, 아이의 신호들을 정확하게 해석 한다.” 등이 포함된다. 문항 간 신뢰도(Cronbach's $\alpha$ )는 가르치 는/물질적 자극 양육 .67, 제한설정 양육 .57 , 민감성 .92이었 고, 전체 신뢰도는 .91이었다

\section{연구절차 및 자료분석}

본 연구는 본교 연구윤리심의위원회(IRB)의 승인을 얻은 후 2018년 2월 21일 2018년 2월 28일에 리서치 기관에 의뢰하 여 조사되었다. 리서치 기관 의뢰 시, 연구에 대한 상세한 설명 과 함께 연구 참가 설명서와 질문지를 전달하였다. 리서치 기 관으로부터 모집된 연구 참가자들은 한 차례의 온라인 설문에 참가하였다. 연구 참가자들은 연구 참가 설명서를 읽은 후, 연 구 참가 동의 여부를 (1) 예, (2) 아니오 중 해당 번호로 표시한 후, 설문에 참가하였고, 참가 설명서와 질문지를 읽고 동의하 는 데 약 15-25분 정도 소요되었으며 검사의 문항은 총 95문항 이었다. 필요시 연구자에게 연락을 취해 질문할 수 있도록 하
였다. 총 310 부를 본 분석에 사용하였다.

본 연구에서 수집된 자료는 SPSS 23.0 (IBM Co., Armonk, $\mathrm{NY}$ )과 AMOS 21.0 (IBM Co., Armonk, NY)을 사용하여 다음 과 같이 분석하였다. 첫째, 연구 참가자의 사회인구학적 특성 을 파악하기 위하여 빈도분석을 실시하였고 각 척도의 신뢰도 를 검증하기 위해 신뢰도(Cronbach's $\alpha$ )를 산출하였다. 둘째, 빈도분석을 통해 각 척도의 측정변인들의 평균 및 표준편차, 왜도와 첨도를 산출하여 어머니의 아동기 애착, 아버지의 양 육참여, 어머니의 양육효능감, 어머니의 양육행동 등 연구 변 인에 대한 정규분포(normal distribution)를 검토하였다. 또한, 연구변인들 간의 관계를 알아보기 위해 상관계수를 산출하였 다. 셋째, 연구변인들 간의 경로를 확인하기 위해 구조방정식 모형(structural equation modeling)을 검증하였다. 우선, 구조모 형의 분석에 앞서, 측정변수들이 각 잠재변수를 적절하게 반 영하는지 확인하기 위해 확인적 요인분석(Confirmatory Factor Analysis [CFA])을 실시하였다. 또한, 매개효과의 유의성을 평 가하기 위해 부트스트래핑(bootstrapping) 방법을 실시하였다.

\section{Results}

\section{연구변인들 간의 상관관계}

연구변인들 간의 관계를 알아보기 위해 Pearson의 상관계수를 산출한 결과, 대부분의 변인들 간에 유의한 상관관계가 나타 났다(Table 1).

\section{어머니의 아동기 애착 및 아버지의 양육참여와 어머니의 양육효능감이 어머니의 양육행동에 영향을 미치는 경로}

\section{측정모형 분석}

본 연구의 구조방정식 모형의 검증에 앞서, 어머니의 아동기 애 착과 아버지 양육참여, 어머니의 양육효능감 및 어머니의 양 육행동 개념들에 대하여 측정변수들이 각 잠재변수를 적절하 게 설명하는지 평가하기 위해 확인적 요인분석(CFA)을 실시하 여 타당성을 확인한 결과, 본 모형의 $\chi^{2}$ 값은 53.275 로 유의하였 다 $(p<.001) . \chi^{2} / d f$ 는 3.552 로서 기준치인 3 이하에 다소 미흡하 였다. 본 모형의 RMSEA의 수치는 .091으로서 보통에 해당하 였고, RMR 수치는 .013으로서 매우 좋음에 해당하였다. 또한, 
Table 1

Correlations Among Maternal Childhood Attachment, Paternal Involvement, Maternal Parenting Efficacy and Parenting Behavior

\begin{tabular}{|c|c|c|c|c|c|c|c|c|}
\hline & 1 & 2 & 3 & 4 & 5 & 6 & 7 & 8 \\
\hline \multicolumn{9}{|l|}{ Childhood attachment } \\
\hline 1. Attachment to mother & - & & & & & & & \\
\hline 2. Attachment to father & $.46^{* * *}$ & - & & & & & & \\
\hline \multicolumn{9}{|l|}{ Paternal involvement } \\
\hline 3. Paternal involvement & .09 & -.01 & - & & & & & \\
\hline \multicolumn{9}{|l|}{ Parenting efficacy } \\
\hline 4. Efficacy as a parent & $.23^{* * *}$ & $.18^{*}$ & $.32^{* * *}$ & - & & & & \\
\hline 5. Anxiety as a parent & $-.29^{* * *}$ & $-.23^{* * *}$ & -.02 & $.37^{* * *}$ & - & & & \\
\hline \multicolumn{9}{|l|}{ Parenting behavior } \\
\hline 6. Didactic-material stimulation & $.22^{* * *}$ & $.25^{* * *}$ & $.32^{* * *}$ & $.52^{* * *}$ & $-.19^{* * *}$ & - & & \\
\hline 7. Limit setting & .04 & .04 & $.15^{* *}$ & $.25^{* * *}$ & $.12^{*}$ & $.24^{* * *}$ & - & \\
\hline 8. Sensitivity & $.22^{* * *}$ & $.17^{* *}$ & $.34^{* * *}$ & $.59^{* * *}$ & $-.30^{* * *}$ & $.53^{* * *}$ & $.20^{* * *}$ & - \\
\hline$M$ & 2.87 & 2.53 & 3.04 & 2.78 & 2.35 & 2.82 & 2.65 & 3.08 \\
\hline$S D$ & .44 & .47 & .60 & .37 & .45 & .43 & .52 & .35 \\
\hline
\end{tabular}

Note. $N=310$.

${ }^{*} p<.05{ }^{* *} p<.01{ }^{* * *} p<.001$.

TLI는 .862으로서 기준치인 0.9 이상에 다소 미달하였다. CFI는 .926으로서 기준치인 0.9 이상에 부합하였다. 또한, 본 연구의 연 구변인들 가운데 아버지의 양육참여는 하나의 잠재변수를 하나 의 측정변수로 측정하는 경우에 속한다. 이러한 경우, 보통 오차 변수의 분산을 특정 값으로 고정하여 식별문제를 해결하는 방 법이 사용된다. 일반적으로 오차분산을 0 으로 고정하거나, 측정 의 신뢰도를 알 수 있는 경우 ‘측정변수의 분산×(1-신뢰도)'로 고 정하는 방법을 사용한다(Jöreskog \& Sörbom, 1996). 어떤 수치로 고정하든 적합도는 동일하나, 신뢰도를 사용할 경우 측정오차 의 추정치를 반영한다는 점에(Kang, 2013) 근거하여 본 연구에서 는 '측정변수의 분산×(1-신뢰도)'의 값으로 고정시켰다.

다음으로, 잠재변수를 측정하기 위한 측정변수가 잘 구성되 어 있는지를 나타내는 수렴타당도(convergent validity)를 확인하 였다. 첫째, 각 잠재변수로부터 측정변수로 향하는 경로는 모 두 유의하였다. 어머니의 아동기 애착 가운데 어머니 애착에 대 한 표준화계수( $\beta$ )는 .692이었으며, 아버지 애착에 대한 표준화 계수 $(\beta)$ 는 .672이었다 $(p<.001)$. 아버지의 양육참여의 아버지의 양육참여에 대한 표준화계수 $(\beta)$ 는 .949이었다 $(p<.001)$. 어머니 의 양육효능감에 대한 표준화계수( $\beta$ )는 .938 , 부모로서의 불안 감에 대한 표준화계수 $(\beta)$ 는 -.398이었다 $(p<.001)$. 어머니의 양 육행동의 가르치는/물질적 자극 양육에 대한 표준화계수( $\beta)$ 는 .699, 제한설정 양육에 대한 표준화계수( $\beta$ )는 .298, 민감성에 대 한 표준화계수 $(\beta)$ 는 . 760 이었다 $(p<.001)$. 둘째, 제한설정 양육
( $\beta=.298)$ 을 제외한 모든 측정변수의 표준화계수( $\beta)$ 는 .30이상 으로 기준치(Heller, Robinson, Henry, \& Plunkett, 2007)에 부합 하였다. 셋째, 모든 잠재변수의 평균분산추출(AVE)은 0.5 이상 으로 기준치에 부합하였다. 마지막으로, 모든 잠재변수의 개념 신뢰도는 0.7 이상으로서 기준치에 부합하였다.

마지막으로, 잠재변수 간에 유사성이 지나치게 높지 않은 지를 확인하기 위해 판별타당도(discriminant validity)를 확인 하였다. 변수 간 결정계수 $\left(R^{2}\right)$ 가 각 변수의 평균분산추출(Average Variance Extracted [AVE]) 값에 비해 낮은지 확인한 결과는 다음과 같다. 어머니의 아동기 애착과 아버지의 양육참여 간 결정계수 .004의 경우는 두 변수의 AVE 모두에 비해 낮았다. 어머니의 아동기 애착과 어머니의 양육효능감 간 결정계수 .118 의 경우는 두 변수의 AVE 모두에 비해 낮았다. 어머니의 아동기 애착과 어머니의 양육행동 간 결정계수 .173 의 경우는 두 변수의 AVE 모두에 비해 낮았다. 어머니의 양육효능감과 아버지의 양육참여 간 결정계수 .125 의 경우는 두 변수의 AVE 모두에 비해 낮았다. 어머니의 양육효능감과 어머니의 양육행 동 간 결정계수 .672의 경우는 두 변수의 AVE 모두에 비해 낮 았다. 어머니의 양육행동과 아버지의 양육참여 간 결정계수 .230의 경우는 두 변수의 AVE 모두에 비해 낮았다. 이상과 같 이, 본 연구의 잠재변수는 수렴타당도와 판별타당도가 대체로 충분한 것으로 볼 수 있다. 


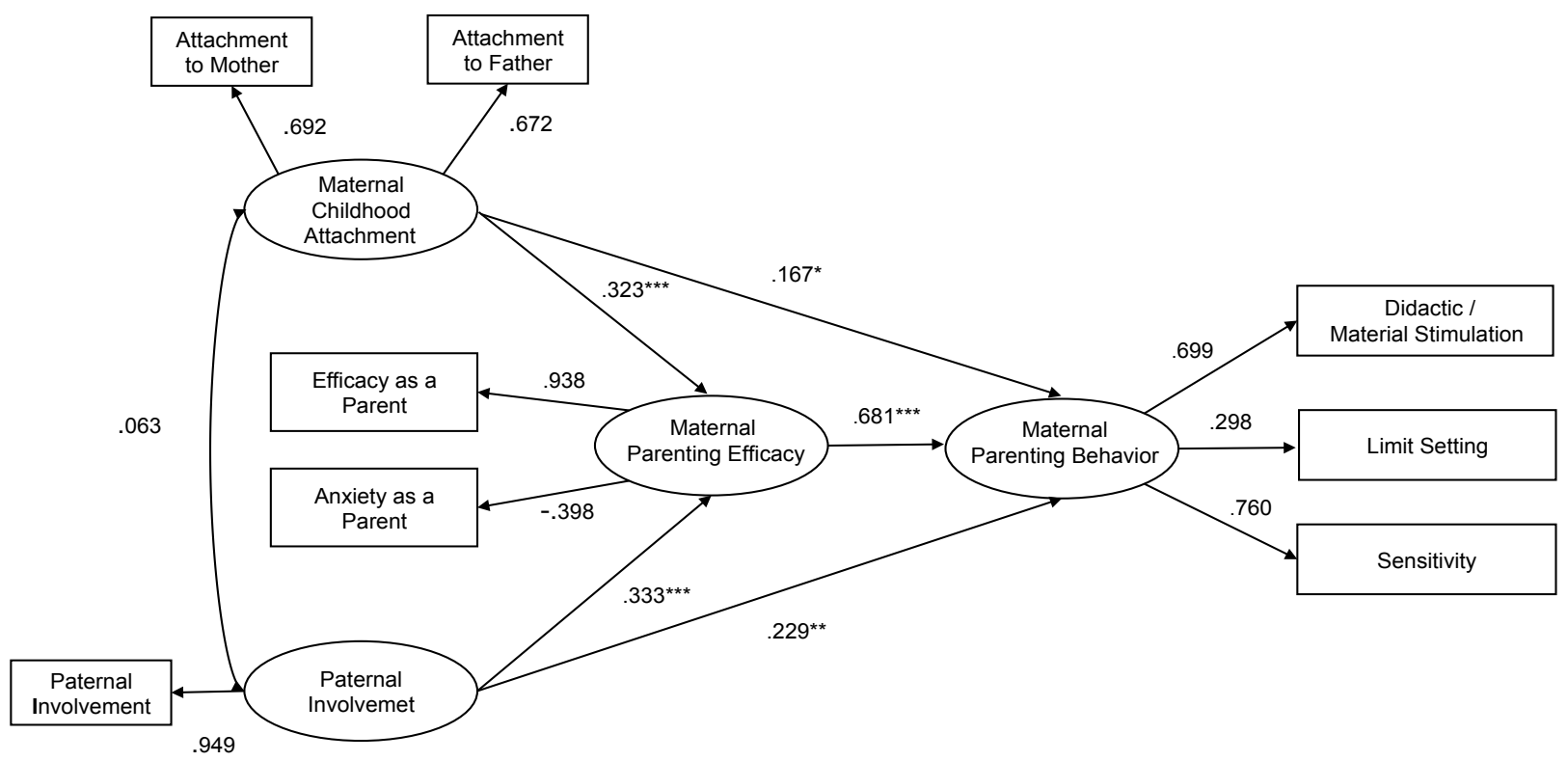

Figure 1. Direct and indirect paths from maternal childhood attachment, paternal involvement and maternal parenting efficacy to maternal parenting behavior.

${ }^{*} p<.05 .{ }^{* *} p<.01 .{ }^{* * *} p<.001$.

\section{구조모형 분석}

어머니의 아동기 애착 및 아버지 양육참여와 어머니의 양육 효능감이 어머니의 양육행동에 어떠한 경로로 영향을 미치 는지를 확인하기 위하여 구조모형을 분석하였다. 그 결과, 구 조모형의 적합도 지수는 $\chi^{2}=53.275(d f=15, p<.001), \chi^{2} / d f$ $=3.552, \mathrm{RMR}=.013, \mathrm{TLI}=.862, \mathrm{CFI}=.926, \mathrm{RMSEA}=.091$ 로 본 구조모형은 적합한 것으로 나타났다.

본 연구결과를 직접 경로와 간접 경로로 나누어 서술하면 다음과 같다. 어머니의 아동기 애착과 아버지의 양육참여가 각각 어머니의 양육행동에 영향을 미치는 직접 경로와 관련하 여, 어머니의 아동기 애착 $(\beta=.17, p<.05)$ 과 아버지의 양육참 여 $(\beta=.23, p<.01)$ 모두 어머니의 양육행동에 유의한 영향을 미쳤다. 즉, 어머니의 아동기 애착이 안정적이고 아버지의 양 육참여가 많을수록, 어머니들은 가르치는/물질적 자극 양육, 일관된 제한설정 및 민감한 양육 등 긍정적 양육행동을 많이 나타내었다. 어머니의 아동기 애착과 아버지의 양육참여, 어 머니의 양육효능감 및 어머니의 양육행동 간의 간접경로를 살 펴보면 다음과 같다. 먼저, 어머니의 아동기 애착은 어머니의 양육효능감 $(\beta=.32, p<.001)$ 에, 어머니의 양육효능감은 어머 니의 양육행동에 $(\beta=.68, p<.001)$ 유의한 영향을 미쳤다. 즉, 어머니의 아동기 애착이 안정적일수록 어머니의 양육효능감 이 높고, 이는 긍정적 양육행동으로 이어졌다.
다음으로, 어머니의 아동기 애착과 아버지의 양육참여가 어머니의 양육효능감을 통해 어머니의 양육행동에 영향을 미 치는 간접 경로와 관련하여, 아버지의 양육참여는 어머니의 양육효능감 $(\beta=.33, p<.001)$ 에, 어머니의 양육효능감은 어머 니의 양육행동에 $(\beta=.68, p<.001)$ 유의한 영향을 미쳤다. 즉, 아버지의 양육참여가 많을수록, 어머니의 양육효능감이 높았 고, 이는 긍정적 양육행동으로 이어졌다.

종합해보면, 어머니의 아동기 애착과 아버지의 양육참여는 어머니의 양육행동에 직접적으로 뿐만 아니라 어머니의 양육효 능감을 통해 간접적으로도 영향을 미쳤다. 어머니의 아동기 애 착 및 아버지의 양육참여와 어머니의 양육효능감이 어머니의 양육행동에 미치는 연구모형의 검증 결과를 제시하면 Figure 1 과 같다.

한편, 잠재변인들 간의 구조적 관계를 보다 명확하게 확인 하기 위하여 부트스트랩핑 방법을 사용하여 변인들 간의 간접 효과의 유의성을 살펴보았다. 어머니의 아동기 애착 및 아버지 의 양육참여와 어머니의 양육효능감이 어머니의 양육행동에 미 치는 직접효과, 간접효과 및 총효과를 살펴본 결과, 어머니의 아동기 애착이 어머니의 양육행동에 이르는 직접효과 $(\beta=.17, p$ $<.05)$ 와 간접효과 $(\beta=.22, p<.01)$ 와 아버지의 양육참여가 어머 니의 양육행동에 이르는 직접효과 $(\beta=.23, p<.01)$ 와 간접효과 $(\beta$ $=.23, p<.01)$ 는 모두 유의하였다. 또한, 어머니의 양육행동에 대한 총효과가 가장 큰 변인은 어머니의 양육효능감 $(\beta=.68, p$ 
<.001)이었으며, 그 다음은 아버지의 양육참여 $(\beta=.46, p<.01)$, 어머니의 아동기 애착 $(\beta=.39, p<.01)$ 순이었다. 어머니의 양육 행동과 어머니의 양육효능감을 설명하는 다중상관치(squared multiple correlations)는 각각 .74과 .23이었다.

\section{Discussion}

본 연구는 6-15개월의 영아기 자녀를 둔 어머니들을 대상으로 어머니의 아동기 애착 및 아버지의 양육참여와 어머니의 양육효 능감이 어머니의 양육행동에 영향을 미치는 경로를 살펴보는 것 을 주목적으로 하였다. 즉, 어머니의 아동기 애착과 아버지의 양 육참여가 어머니의 양육행동에 미치는 직접적 영향과 어머니의 양육효능감을 통한 간접적 영향을 살펴보았다. 본 연구결과를 직접 경로와 간접 경로로 구분하여 논의하면 다음과 같다.

\section{어머니의 아동기 애착 및 아버지의 양육참여 와 어머니의 양육행동 간의 직접 경로}

어머니의 아동기 애착 및 아버지의 양육참여와 어머니의 양육 행동 간의 직접 경로와 관련하여, 어머니의 아동기 애착과 아 버지의 양육참여 모두 어머니의 양육행동에 직접적 영향을 미 쳤다. 먼저, 어머니의 아동기 애착이 안정적일수록 어머니들 은 민감한 양육, 가르치는/물질적 자극 양육, 일관된 제한설정 을 많이 하였다.

이러한 결과는 어머니의 아동기 발달역사가 훗날의 자녀 양육행동에 중요한 영향을 미친다는 Belsky (1984)의 이론을 지지한다. 이는 자신의 유년 시절, 어머니에 대한 애착의 기억 들이 현재 자녀와의 관계 및 민감한 양육행동에 영향을 미치 는 것으로 보고된 연구결과들(Bowlby, 1969; Eiden et al., 1995; Slade, Belsky, Aber, \& Phelps, 1999)과 일치한다. 또한, 어머니 가 자신의 부모와 안정 애착을 형성할수록 자녀 양육 시 합리 적 지도, 온정적, 성취적, 적극적 참여, 일관성 있는 규제, 자 율격려의 양육행동을 더 많이 수행하며, 권위주의적 통제, 거 부 - 방임의 양육행동을 덜 하는 것으로 보고한 연구결과들 (Chyung, 2008; Cohn, Cowan, Cowan, \& Pearson, 1992)과도 부 분적으로 일치한다. 이러한 결과는 인생의 초기에 형성된 인 간관계에 대한 인지적 내적 실행모델을 강조한 애착이론의 관 점(Bowlby, 1973)에서도 해석할 수 있다. 어머니의 원가족에서 의 경험은 자녀양육 과정에서 영향을 받게 되는 중요한 사회 적 관계로, 어머니들은 자녀양육 시 자신의 부모와의 관계에
대한 내적표상을 어머니 자신과 자녀와의 관계에 투영할 수 있다. 즉, 원가족과의 긍정적 경험을 통해 안정적 내적 실행모 델을 지닌 어머니들은 더 민감하게 반응하는 긍정적 양육행동 을 수행하게 될 것이다. 또한, 어머니가 아동기 원가족과의 관 계 속에서 경험한 부모의 양육태도가 어머니의 행동에 강력한 역할 모델로 작용할 수 있다는 점에서 사회학습이론의 관점 (Bandura \& Walters, 1959)에서도 해석할 수 있다. 다시 말하면, 아동기 원가족에서의 정서적 유대와 긍정적 경험은 어머니의 안정 애착으로 이어지고, 긍정적 양육행동을 모델링하게 되어 긍정적 양육행동을 이끌어내는 것으로 보인다.

다음으로, 아버지의 양육참여가 많을수록, 어머니는 민감 한 양육, 가르치는/물질적 양육, 일관된 제한설정을 더 많이 보였다. 이러한 결과는 영아기 동안 아버지의 직접적 양육참 여는 어머니의 양육행동에 영향을 미친다고 보고한 연구결과 들(Fuertes, Faria, Beeghly, \& Lopes-dos-Santos, 2016; HohmannMarriott, 2011)과 일치한다. 또한, 아버지의 양육참여가 많을 경우, 어머니가 민감하고 반응적인 양육행동과 합리적 지도, 온정적, 수용적 양육행동을 많이 보이는 반면, 아버지의 양 육참여가 적을 경우, 명령적 언어표현, 방임 - 허용 또는 통제 와 같은 부정적 양육행동을 더 많이 한다는 연구결과들 $(\mathrm{K} . \mathrm{J}$. Park, Park, \& Chung, 2017; Seo \& Lee, 2014)과도 부분적으로 일치한다. 다시 말하면, 영아와의 놀이 활동이나 목욕시키기 등과 같은 일상생활에 더 많이 참여하는 아버지들은 어머니의 양육행동에 직접적 영향을 미쳐 어머니의 민감하고 반응적인 양육행동에 긍정적인 역할을 하는 것으로 보인다. 본 연구결 과는 배우자의 양육참여를 통한 사회 - 정서적 지지는 어머니 의 양육행동과 관련하여 그 영향력이 강력하고, 배우자의 양 육참여를 바탕으로 형성된 친밀한 부부관계는 어머니의 긍정 적 양육행동과 관련이 높고, 자녀양육 과정에서 가장 중요한 자원이라는 Belsky (1984)의 주장과 유사하다.

이러한 결과는 영아기의 발달적 특성에 입각하여 아버지의 도구적 도움과 정서적 지지와 관련된 내용들을 중심으로 한 부모교육의 중요성을 강조한다.

\section{어머니의 아동기 애착 및 아버지의 양육참여, 어 머니의 양육효능감 및 어머니의 양육행동 간의 간접 경로}

어머니의 아동기 애착, 양육효능감 및 양육행동 어머니의 아동기 애착이 양육효능감을 통해 양육행동에 영향 
을 미치는 간접 경로와 관련하여, 어머니의 아동기 애착이 안 정적일수록 양육효능감이 높았고, 이는 민감하게 반응하는 긍 정적 양육행동으로 이어졌다. 본 연구결과를 어머니의 아동기 애착과 어머니의 양육효능감 간의 경로, 어머니의 양육효능감 과 어머니의 양육행동 간의 경로, 그리고 어머니의 아동기 애 착, 양육효능감 및 양육행동 간의 경로 등 세 가지로 나누어 논 의하면 다음과 같다.

어머니의 아동기 애착과 어머니의 양육효능감 간의 경로 와 관련하여, 본 연구결과는 원가족 부모와 의 관계에 관한 긍 정적 인식은 어머니로 하여금 높은 효능감을 갖게 한다는 연 구결과(Suzuki et al., 2009)와 일치한다. 또한, 일본과 미국의 어 머니들을 대상으로 한 연구에서 일본의 어머니들 가운데 유년 시절 원가족 부모로부터 많은 사랑과 수용을 받았다고 보고한 어머니들은 높은 양육효능감을 보였고(Holloway \& Behrens, 2002), 그들의 후속 연구에서 시간이 경과된 후에도 원가족 부 모와의 관계에 대한 지각과 어머니의 양육효능감 간의 정적인 상관관계는 동일하게 유지되었다는 연구결과(Behrens, Hesse, $\&$ Main, 2007)와 일치한다. 즉, 이는 어머니가 아동기에 경험 한 자신의 부모의 양육태도나 역할 모델이 어머니의 양육효능 감에 영향을 미친다. 양육효능감이 높은 어머니들은 자신의 감정에 확신이 있고, 부정적 정서를 낮은 강도로 지각하며 자 신의 감정과 행동을 조절할 수 있는 능력을 가지고 있다. 또한, 원부모의 긍정적 부부관계를 관찰하고, 적응적으로 기능하는 가족환경에서 성장한 어머니들은 배우자 및 자녀와의 관계가 훨씬 더 안정적이 되어(Bowlby, 1969), 양육효능감이 증가한 다. 특히, 영아기 자녀를 둔 어머니의 경우, 아버지보다 부모가 되는 과정에서 경험하는 초기 스트레스가 크고, 부모로서의 역할에 대한 책임감과 부담이 더 크므로 다른 어떤 시기보다 어머니의 양육효능감이 중요하다고 할 수 있다.

어머니의 양육효능감과 어머니의 양육행동 간의 경로와 관 련하여, 본 연구결과는 영아기 자녀를 둔 어머니의 양육효능 감과 어머니의 양육행동 간의 직접적 경로를 보고한 연구결과 (J.-Y. Lee, 2009)와 일치하고, 영아기 자녀를 둔 어머니들을 대 상으로 어머니의 양육효능감과 민감성 간의 정적 상관을 발 견한 연구결과(Crockenberg \& Smith, 2002)와 일치한다. 또한, 3-13개월 영아기 자녀를 둔 어머니를 대상으로 어머니의 상호 작용 행동에 영향을 미치는 요인과 관련하여, 영아의 까다로 운 기질에 대한 어머니의 인식, 어머니의 우울, 사회적 지원 등 이 양육효능감을 매개로 하여 양육행동에 영향을 미친다고 보 고한 연구결과(Teti \& Gelfand, 1991)와도 유사하다. 그 외에도 양육효능감이 높은 어머니는 자녀에게 수용적이고 민감한 긍
정적 양육행동을 보이고 양육효능감이 낮은 어머니는 자녀에 게 통제적이고 강압적이며 민감하지 못한 부정적 양육행동을 보인다는 연구결과들(Coleman \& Karraker, 1997; Yoon \& Cho, 2011)과 유사하다.

양육효능감은 복합적 요인들에 기반한 판단으로 부모들 이 적절한 양육에 대한 지식과 기술을 일상생활에 적용할 수 있는 능력에 있어서의 자신감을 의미하므로(Coleman \& Karraker, 1997) 상황에 따른 어머니의 인지적 특성에 따라 효 능감을 지각하는 수준은 다를 수 있다. 특히, 영아기는 양육으 로 인한 신체적 피로감과 부모됨에 적응하는 과정에서 어머 니의 양육스트레스가 상당히 높아질 수 있는 시기이다(Kwon, 2011). 영아기 자녀를 둔 어머니의 양육스트레스는 출산 후 3 년까지 유의하게 증가하며(S. O. Hwang \& Hwang, 2015), 특 히, 15-36개월에 이르러 양육스트레스는 절정에 이른다(Crnic \& Booth, 1991). 영아기 자녀를 둔 어머니가 부모로서의 역할 수행에 대한 자신감인 양육효능감이 부족할 경우, 자녀양육에 있어 더 큰 어려움을 경험하기 쉽다. 따라서 영아기 자녀를 둔 어머니들의 양육효능감 향상을 돕는 것은 궁극적으로 아동발 달에 긍정적 영향을 미칠 뿐만 아니라 아동학대의 위험을 예 방할 수 있다는 점에서 매우 중요해 보인다.

어머니의 아동기 애착, 양육효눙감 및 양육행동 간의 경로 와 관련하여, 본 연구결과는 아동기에 어머니가 원가족과의 관계를 긍정적으로 인식하고, 정서적으로 건강한 분리를 경 험하고, 정서적 단절을 적게 경험하고, 적절한 수용과 독립성 을 보장받았다고 지각할수록 어머니의 아동기 애착이 안정 적으로 형성되어 자녀양육 과정에서 높은 양육효능감을 보 이고 자녀에게 온정적, 합리적, 적절한 한계설정 및 즉각적인 반응성을 보이는 긍정적 양육행동이 증가한다는 연구결과들 (J. H. Jeon, 2009; Mun, 2013)과 일치한다. 다시 말해서, 원가 족에서의 부모와의 관계적 경험들을 어떻게 지각하느냐에 따 라 궁극적으로 자신의 현재 양육행동이 달라질 수 있음을 의 미한다. 이는 자율성과 자기지시 능력을 바탕으로 원가족으로 부터 정서적, 신체적으로 자신을 독립할 수 있는 능력을 의미 하는 Bowen (1976)의 자아분화 개념의 측면에서 해석할 수 있 다. 즉, 효과적으로 기능하는 가족 환경에서 성장한 개인은 자 아분화 수준이 높고, 자신의 감정 과정을 정확히 인식할 수 있 기 때문에 자녀양육 시 자녀의 감정에 대한 공감능력이 높고, 자녀의 자율성을 지지하는 아동중심적 양육행동을 더 많이 하 게 될 것이다. 또한, 자아분화가 잘 이루어진 부모는 타인과의 친밀한 관계형성을 중요하게 생각하면서도 독립성을 추구한 다는 점에서(Bowen, 1976), 자녀를 자신의 소유물이 아닌 인격 
적 존재로 인식하게 되어, 자녀의 단점보다는 장점에 더 큰 가 치를 두고, 자녀에 대한 불만과 지적이 적어, 상호존중적인 부 모-자녀관계를 형성할 수 있을 것이다. 다시 말하면, 아동기에 부모로부터 정서적으로 건강한 분리를 경험하고, 어머니의 자 아분화 수준이 높을수록 어머니는 안정적인 아동기 애착을 형 성하게 되고, 어머니의 양육효능감이 높아져서, 영아기 자녀 의 정서적 신호에 민감하게 반응하는 긍정적 양육행동을 수행 하게 될 것이다.

아버지의 양육참여, 어머니의 양육효능감 및 어머 니의 양육행동

아버지의 양육참여가 어머니의 양육효능감을 통해서 어머니 의 양육행동에 미치는 간접 경로와 관련하여, 아버지의 양육 참여가 많을수록 어머니의 양육효능감이 높아졌고, 이는 민감 하게 반응하는 긍정적 양육행동으로 이어졌다. 본 연구결과를 앞서 서술한 어머니의 양육효능감과 어머니의 양육행동 간의 경로를 제외하고, 아버지의 양육참여와 어머니의 양육효능감 간의 경로와 아버지의 양육참여, 어머니의 양육효능감 및 어 머니의 양육행동 간의 경로의 두 가지로 나누어 논의하면 다 음과 같다.

아버지의 양육참여와 어머니의 양육효능감 간의 경로와 관련하여, 본 연구결과는 배우자의 직접적 양육참여를 통한 사회적 지지는 다른 사회적 지지보다 그 영향력이 횔씬 크고 (Shapiro \& Mangelsdorf, 1994), 어머니의 양육효능감을 예측하 는 가장 영향력 있는 변인으로 간주된다는 연구결과들(Belsky \& Vondra, 1989; Choe \& Chung, 2005; Cochran \& Niego, 1995) 과 일치한다. 특히, 어머니의 양육부담이 더 많은 발달장애 아 동의 어머니들의 경우 아버지의 양육참여를 통한 지지가 높을 수록, 어머니의 심리적 안정감과 양육효능감이 높은 것으로 보고된 연구결과(M.-Y. Jeon \& Park, 2011)와 일치한다. 또한, 아버지의 양육참여 가운데 도구적 도움의 측면인 아버지의 생 활지도 요인이 어머니의 양육효능감에 가장 큰 영향을 미쳤 다는 연구결과(Y. M. Hwang \& Moon, 2006)와도 유사하다. 이 는 자녀양육 과정에서 아버지의 양육참여가 많을수록 어머니 는 부모로서의 자신의 역할에 대한 부담과 갈등을 적게 느끼 게 되어 결과적으로 양육효능감이 높아진다는 것을 의미한다. 즉, 아버지의 양육참여는 어머니에게 사회적 지지를 제공하게 된다. 특히, 영아 잠재우기, 음식과 간식 먹이기, 목욕시키기, 기저귀 갈아주기 등의 일상적 과업을 돕는 아버지의 도구적 도움은 영아기 자녀를 둔 어머니의 육체적 피로와 심리적 부
담감을 동시에 경감시켜줄 수 있다는 측면에서 중요하다. 예 를 들어, 배우자가 아내의 양육에 대한 부담을 공감하고 격려 해주지만 도구적 도움을 주지 않는다면 영아기 자녀를 둔 어 머니에게는 실질적으로 도움이 될 수 없을 것이다. 남편이 양 육에 적극적으로 참여함으로써 아내의 어려움을 함께 나누고 공감할 때, 긍정적 정서가 어머니의 양육효능감에 긍정적 영 향을 미치게 될 것이다.

아버지의 양육참여, 어머니의 양육효능감 및 어머니의 양 육행동 간의 경로와 관련하여, 본 연구결과는 영아기 자녀를 둔 아버지의 양육참여는 어머니의 양육효능감을 매개로 어머 니의 민감하고 온정적 양육행동에 직·간접적 영향을 미친다 고 보고한 연구결과(Seo \& Lee, 2014)와 일치한다. 또한, 아버 지의 양육참여를 통한 사회·정서적 지지가 높을수록 어머니 의 일상적 스트레스 수준이 감소하여 양육효능감이 높아지고 (Fuertes et al., 2016), 어머니의 높은 양육효능감은 온정적, 수 용적, 일관된 민감한 양육행동과 관련되고, 자녀의 사회적, 심 리적 발달을 이끌어낸다는 연구결과들(H. M. Kim \& Doh, 2004; Teti \& Gelfand, 1991)과도 일치한다. 배우자가 자녀양육 에 대한 육체적, 정신적 부담을 함께 나누고 지지해주면서 자 녀양육에 협조적으로 참여하면 어머니의 육아부담이 줄어들 게 되어 결혼 만족도가 높아져서 정서적 안정감을 갖게 되고, 자녀양육 시 온정적, 수용적이면서 민감한 양육행동을 이끌어 낸다는 연구결과(K. J. Park et al., 2017)와도 유사하다. 이는 아 버지의 양육참여는 어머니의 자녀양육에 대한 심리적 부담과 양육스트레스를 경감시켜서, 높은 양육효능감 및 효과적이고 긍정적 양육행동을 이끌어 낸다고 해석할 수 있다.

결론적으로, 본 연구에서 어머니의 아동기 애착과 아버지 의 양육참여는 어머니의 양육행동에 직접적으로 뿐만 아니라 어머니의 양육효능감을 통해 간접적으로도 영향을 미쳤다. 본 연구는 어머니의 양육행동에 대해 어머니의 양육효능감, 아버 지의 양육참여, 어머니의 아동기 애착 순으로 영향을 미침을 확인함으로써, 특히 어머니의 양육효능감의 상대적 영향력을 강조하였다. 원가족 부모와의 유년 시절 발달역사가 부모의 양육행동과 이와 관련된 인지와 정서를 예측할지라도, 어머니 의 양육효능감과 아버지의 양육참여를 높임으로써 어머니의 양육행동을 긍정적으로 변화시킬 수 있는 가능성을 내포한다. 본 연구는 어머니의 긍정적 양육행동을 높이기 위해 특히 양 육신념으로서의 양육효능감의 중요성을 강조하는 부모교육 프로그램의 내용을 비롯하여 아버지를 대상으로 하는 부모교 육과 관련하여 시사점이 크다. 특히, 아버지의 도구적 도움과 정서적 지지의 측면을 강조하는 실질적이고 구체적인 교육내 
용의 필요성을 강조한다.

본 연구의 제한점과 후속 연구를 위한 제언을 하면 다음과 같다. 첫째, 본 연구는 어머니의 보고에만 의존함으로써 관찰 에 의한 평가를 반영하지 못하였다. 특히, 영아기는 질문지법 과 관찰법 등 조사방법에 따라 각기 다른 연구결과를 도출해 낼 가능성이 있으므로 후속 연구에서는 좀 더 다양한 연구방 법을 사용하는 것이 권장된다. 따라서 후속 연구에서는 실험 연구방법으로 영아기 자녀와 놀이하는 동안에 다양한 수준의 양육효능감를 지닌 부모들의 민감성 정도를 측정함으로써 자 료를 수집하는 것이 바람직할 것이다. 둘째, 본 연구는 연구변 인들의 관계를 동일한 시점에서 측정하였기 때문에 변인들 간 의 명확한 인과관계를 밝히는 것은 다소 무리가 있다. 이에 후 속 연구에서는 종단적 연구설계를 통해 이를 확인하는 것이 필요하다. 셋째, 어머니의 양육행동 척도 가운데 민감성을 제 외한 가르치는/물질적 자극 양육행동과 제한설정 양육행동 척도의 신뢰도가 다소 낮은 편에 속하였다. 후속 연구에서는 문항 수를 추가한, 보다 정교한 척도를 사용하여 신뢰도를 높 임으로써 이를 보완할 필요가 있다. 넷째, 연구 참가자인 영아 의 월령이 6-15개월이기 때문에 제한설정 양육행동에 관한 해 석에 신중을 기해야할 것이다. 마지막으로 본 연구는 리서치 기관으로부터 모집된 참가자들이 한 차례의 온라인 설문조사 를 통해 연구자료를 수집하였으므로 온라인상에서 연구 참가 자로부터 타당하고 신뢰로운 연구자료를 수집하는데 있어 한 계가 있을 수 있다. 또한, 본 연구에서는 참가자인 영아의 출생 순위의 대다수가 첫 자녀에 속하여 출생순위의 효과를 고려하 지 못하였다. 후속 연구에서는 다양한 출생순위에 속한 영아 들을 표집함으로써 그 영향력을 확인할 필요가 있다.

이러한 제한점에도 불구하고, 본 연구는 다음과 같은 학문 적 의의가 있다. 첫째, 그동안 영아기 자녀를 둔 어머니의 양육 행동과 관련된 국내 연구가 매우 부족한 상황에서 6-15개월의 영아기 자녀를 둔 어머니의 양육행동을 측정하였다는 점에서 학문적 의의가 있다. 둘째, 영아기 자녀를 둔 어머니의 양육행 동과 관련하여, 어머니의 아동기 애착과 같은 개인적 특성, 아 버지의 양육참여와 같은 관계적 변인, 어머니의 양육효능감과 같은 인지적 변인 등 다양한 변인을 포함하여 어머니의 양육 행동에 영향을 미치는 경로를 구조모형을 통하여 검증하였다 는 점에서 의의가 있다. 셋째, 영아기 관련 국내 연구들과 관련 하여, 대부분 어머니의 역할의 중요성에 초점을 둘 뿐만 아니 라 아버지의 양육참여와 어머니의 양육행동 간의 관련성을 살 펴본 연구들이 매우 부족한 실정에 본 연구는 영아기의 어머 니 역할과 아버지 역할의 중요성을 확인하였다는 데 그 의의
가 있다. 마지막으로, 어머니의 아동기 애착과 어머니의 양육 효능감 간의 경로는 상대적으로 덜 조명되어 관련 국내외 연 구들이 매우 부족한 실정에 본 연구는 어머니의 아동기 애착, 양육효능감 및 양육행동 간의 관계를 탐색하였다는 데 학문적 의의가 있다.

본 연구는 영아기 자녀를 위한 부모교육 및 상담, 부모-자 녀관계 및 부부관계 증진 프로그램 등의 프로그램 개발을 위 한 기초 자료로 활용될 수 있을 것이다.

\section{Acknowledgements}

This study was supported by the Ministry of Education of the Republic of Korea and the National Research Foundation of Korea (NRF-2016S1A3A2924375).

\section{Notes}

This article is a part of the first author's doctoral dissertation submitted in 2018

\section{Conflict of Interest}

No potential conflict of interest relevant to this article was reported.

\section{Ethics Statement}

All procedures of this research were reviewed by IRB (EWIRB-17-3.0-20170901).

\section{References}

\section{In English}

Ainsworth, M. D. S., Blehar, M. C., Waters, E., \& Wall, S. (1978). Patterns of Attachment: A psychological study of the strange situation. Hillsdale, NJ: Lawrence Erlbaum Associates, Inc.

Allen, S., \& Daly, K. (2007). The effects of father involvement: An 
updated research summary of the evidence inventory. Retrieved from CANTASD website: https://cantasd.acf.hhs.gov

Bandura, A., \& Walters, R. H. (1959). Adolescent aggression-A study of the influence of child-training practices and family interrelationships. New York: The Ronald Press Company.

Behrens, K. Y., Hesse, E., \& Main, M. (2007). Mothers' attachment status as determined by the adult attachment interview predicts their 6-year-olds' reunion responses: A study conducted in Japan. Developmental Psychology, 43(6), 1553-1567. doi:10.1037/0012-1649.43.6.1553

Belsky, J. (1979). The interrelation of parental and spousal behavior during infancy in traditional nuclear families: An exploratory analysis. Journal of Marriage and the Family, 41(4), 749-755. doi: $10.2307 / 351475$

Belsky, J. (1980). Child maltreatment: An ecological integration. American Psychologist, 35(4), 320-335. doi:10.1037/0003066X.35.4.320

Belsky, J. (1982). In the beginning: Readings on infancy. New York: Columbia University Press.

Belsky, J. (1984). The determinants of parenting: A process model. Child Development, 55(1), 83-96. doi:10.2307/1129836

Belsky, J., \& Vondra, J. (1989). Lessons from child abuse: The determinants of parenting. In D. Cicchetti \& V. Carlson (Eds.), Child maltreatment: Theory and research on the causes and consequences of child abuse and neglect (pp. 153-202). New York: Cambridge University Press. doi:10.1017/ CBO9780511665707.007

Berk, L. E., \& Meyers, A. B. (2002). Infants and children: Prenatal through middle childhood. Boston, MA: Allyn \& Bacon.

Biringen, Z. (1990). Direct observation of maternal sensitivity and dyadic interactions in the home: Relations to maternal thinking. Developmental Psychology, 26(2), 278-284. doi:10.1037/0012-1649.26.2.278

Bornstein, M. H., \& Tamis-LeMonda, C. S. (1989). Maternal responsiveness and cognitive development in children. New Directions for Child and Adolescent Development, 1989(43), 49-61. doi:10.1002/cd.23219894306

Bowen, M. (1976). Theory in the practice of psychotheraphy. In P. J. Guerin (Ed.), Family therapy: Theory and practice (pp. 4290). New York: Gardner Press.

Bowlby, J. (1969). Attachment and loss: Volume I. Attachment. New York: Basic Books.

Bowlby, J. (1973). Attachment and loss: Volume II. Separation: Anxiety and anger. New York: Basic Books.

Braungart-Rieker, J., Garwood, M. M., Powers, B. P., \& Notaro, P. C. (1998). Infant affect and affect regulation during the still-face paradigm with mothers and fathers: The role of infant characteristics and parental sensitivity. Developmental Psychology, 34(6), 1428-1437.

Brown, G. W., \& Harris, T. (1978). Social origins of depression: A study of psychiatric disorder in women. London: Tavistock Publications.

Brown, M., Larson, J., Harper, J., \& Holman, T. (2016). Familyof-origin experience and emotional health as predictors of relationship self-regulation in marriage. Journal of Family Therapy, 38(3), 319-339. doi:10.1111/1467-6427.12066

Caldwell, J. G., Shaver, P. R., Li, C.-S., \& Minzenberg, M. J. (2011). Childhood maltreatment, adult attachment, and depression as predictors of parental self-efficacy in at-risk mothers. Journal of Aggression, Maltreatment \& Trauma, 20(6), 595-616. doi:10.1080/10926771.2011.595763

Chamberlain, P., \& Patterson, G. R. (1995). Discipline and child compliance in parenting. In M. H. Bornstein (Ed.), Handbook of parenting, Volume. 4. Applied and practical parenting (pp. 205-225). Hillsdale, NJ: Lawrence Erlbaum Associates, Inc.

Cochran, M., \& Niego, S. (1995). Parenting and social networks. In M. H. Bornstein (Ed.), Handbook of parenting, Volume 3. Status and social conditions of parenting (pp. 393-418). Hillsdale, NJ: Lawrence Erlbaum Associates, Inc.

Cohn, D. A., Cowan, P. A., Cowan, C. P., \& Pearson, J. (1992). Mothers' and fathers' working models of childhood attachment relationships, parenting styles, and child behavior. Development and Psychopathology, 4(3), 417-431. doi:10.1017/S0954579400000870

Coleman, P. K., \& Karraker, K. H. (1997). Self-efficacy and parenting quality: Findings and future applications. Developmental Review, 18(1), 47-85. doi:10.1006/ drev. 1997.0448

Crnic, K. A., \& Booth, C. L. (1991). Mothers' and fathers' perceptions of daily hassles of parenting across early childhood. Journal of Marriage and the Family, 53(4), 1042-1050. doi:10.2307/353007

Crnic, K. A., Greenberg, M. T., Ragozin, A. S., Robinson, N. M., \& Basham, R. B. (1983). Effects of stress and social support on mothers and premature and full-term infants. Child Development, 54(1), 209-217. doi:10.2307/1129878

Crockenberg, S. B., \& Smith, P. (2002). Antecedents of motherinfant interaction and infant irritability in the first 3 months of life. Infant Behavior \& Development, 25(1), 2-15. doi:10.1016/S0163-6383(02)00088-7

Eiden, R. D., Teti, D. M., \& Corns, K. M. (1995). Maternal working models of attachment, marital adjustment, and the parent-child relationship. Child Development, 66(5), 15041518. doi:10.1111/j.1467-8624.1995.tb00948.x

Frommer, E. A., \& O’Shea, G. (1973). Antenatal identification of women liable to have problems in managing their infants. British Journal of Psychiatry, 123(573), 149-156. doi:10.1192/bjp.123.2.149

Fuertes, M., Faria, A., Beeghly, M., \& Lopes-dos-Santos, P. (2016). 
The effects of parental sensitivity and involvement in caregiving on mother-infant and father-infant attachment in a Portuguese sample. Journal of Family Psychology, 30(1), 147-156.

George, C., Kaplan, N., \& Main, M. (1985). Adult attachment interview protocol. Retrieved from http://www.psychology.sunysb.edu/ attachment

Harris, K. M., \& Morgan, S. P. (1991). Fathers, sons, and daughters: Differential paternal involvement in parenting. Journal of Marriage and the Family, 53(3), 531-544. doi:10.2307/352730

Heller, S. R., Robinson, L. C., Henry, C. S., \& Plunkett, S. W. (2007). Gender differences in adolescent perceptions of parentadolescent openness in communication and adolescent empathy. Marriage \& Family Review, 40(4), 103-122.

Hohmann-Marriott, B. (2011). Coparenting and father involvement in married and unmarried coresident couples. Journal of Marriage and Family, 73(1), 296-309. doi:10.1111/j.17413737.2010.00805.x

Holloway, S. D., \& Behrens, K. Y. (2002). Parenting self-efficacy among Japanese mothers: Qualitative and quantitative perspectives on its association with childhood memories of family relations. New Directions for Child and Adolescent Development, 2002(96), 27-43.

Jeon, H.-J. (1994). Conflict resolution and marital adjustment in Korean couples: Influences of attachment style, marital comparison, and motivations (Doctoral dissertation). Retrieved from http://www.riss.kr/link?id=T8442608

Jöreskog, K. G., \& Sörbom, D. (1996). LISREL 8: User's reference guide. Lincolnwood, IL: Scientific Software International, Inc.

Kohlhoff, J., \& Barnett, B. (2013). Parenting self-efficacy: Links with maternal depression, infant behaviour and adult attachment. Early Human Development, 89(4), 249-256. doi:10.1016/ j.earlhumdev.2013.01.008

Leerkes, E. M., \& Crockenberg, S. C. (2002). The development of maternal self-efficacy and its impact on maternal behavior. Infancy, 3(2), 227-247. doi:10.1207/S15327078IN0302_7

Lynn, M. R. (1986). Determination and quantification of content validity. Nursing Research, 35(6), 382-385. doi:10.1097/00006199198611000-00017

Marsiglio, W., Amato, P., Day, R. D., \& Lamb, M. E. (2000). Scholarship on fatherhood in the 1990s and beyond. Journal of Marriage and the Family, 62(4), 1173-1191. doi:10.1111/ j.1741-3737.2000.01173.x

McBride, B. A., \& Mills, G. (1993). A comparison of mother and father involvement with their preschool age children. Early Childhood Research Quarterly, 8(4), 457-477.

McHale, J. P., \& Lindahl, K. M. (2011). Coparenting: A conceptual and clinical examination of family systems. Washington, DC: APA Press.
Pearson, R. M., Heron, J., Melotti, R., Joinson, C., Stein, A., Ramchandani, P. G., \& Evans, J. (2011). The association between observed non-verbal maternal responses at 12 months and later infant development at 18 months and IQ at 4 years: A longitudinal study. Infant Behavior and Development, 34(4), 525-533. doi:10.1016/j.infbeh.2011.07.003

Pereira, J., Vickers, K., Atkinson, L., Gonzalez, A., Wekerle, C., \& Levitan, R. (2012). Parenting stress mediates between maternal maltreatment history and maternal sensitivity in a community sample. Child Abuse \& Neglect, 36(5), 433437. doi:10.1016/j.chiabu.2012.01.006

Pleck, E. H., \& Pleck, J. H. (1997). Fatherhood ideals in the United States: Historical dimensions. In M. E. Lamb (Ed.), The role of the father in child development (pp. 33-48). Hoboken, NJ: John Wiley \& Sons Inc.

Ruìz, M. M. R., Carrasco, M. Á., \& Holgado-Tello, F. P. (2016). Father involvement and children's psychological adjustment: Maternal and paternal acceptance as mediators. Journal of Family Studies, 25(2), 151-169. doi:10.1080/132 29400.2016.1211549

Shapiro, J. R., \& Mangelsdorf, S. C. (1994). The determinants of parenting competence in adolescent mothers. Journal of Youth and Adolescence, 23(6), 621-641.

Slade, A., Belsky, J., Aber, J. L., \& Phelps, J. L. (1999). Mothers' representations of their relationships with their toddlers: Links to adult attachment and observed mothering. Developmental Psychology, 35(3), 611-619. doi:10.1037/0012-1649.35.3.611

Snow, C. E. (1989). Understanding social interaction and language acquisition: Sentences are not enough. In M. H. Bornstein \& J. S. Bruner (Eds.), Crosscurrents in contemporary psychology. Interaction in human development (pp. 83-103). Hillsdale, NJ: Lawrence Erlbaum Associates, Inc.

Suzuki, S., Holloway, S. D., Yamamoto, Y., \& Mindnich, J. D. (2009). Parenting self-efficacy and social support in Japan and the United States. Journal of Family Issues, 30(11), 1505-1526. doi:10.1177/0192513X09336830

Teti, D. M., \& Gelfand, D. M. (1991). Behavioral competence among mothers of infants in the first year: The mediational role of maternal self-efficacy. Child Development, 62(5), 918-929. doi:10.1111/j.1467-8624.1991.tb01580.x

\section{In Korean}

Choe, H. S., \& Chung, O. B. (2005). The causal relations model of Korean mothers' parenting self-efficacy: Focusing on children's temperament and mothers' perceived social support and stress. The Korean Journal of the Human Development, 12(1), 51-67.

Chyung, Y. J. (2008). Attachment experience in childhood, personality characteristics, parenting stress and parenting behavior among mothers with preschool children. Journal 
of the Korean Home Economics Association, 46(3), 73-85.

Hwang, S. O., \& Hwang, Z. O. (2015). The causal relationships between parenting stress and the parenting attitudes of infant mothers. Korean Journal of Child Studies, 36(4), 163176. doi:10.5723/KJCS.2015.36.4.163

Hwang, Y. M., \& Moon, H. J. (2006). Peer acceptance in relation to children's temperament, maternal self-efficacy, and paternal child rearing involvement. Journal of the Korean Home Economics Association, 44(2), 83-91.

Jeon, J. H. (2009). Influence of parents' family-of-origin experience on parenting efficacy and behavior-Focusing on parents with young children-(Master's thesis). Retrieved from http://www. riss.kr/link?id=T11778294

Jeon, M.-Y., \& Park, H.-Y. (2011). Father's involvement in child care and parenting self-efficacy of mothers with developmentally disabled children. The Journal of Korean Society of Occupational Therapy, 19(3), 23-33.

Kang, H. (2013). Discussions on the suitable interpretation of model fit indices and the strategies to fit model in structural equation modeling. Journal of the Korean Data Analysis Society, 15(2), 653-668.

Kim, E., \& Jeon, G. (2016). The influence of perception gap of dual-income parents about paternal involvement on marital conflict: mediating effects of maternal self-efficacy and depression. Family and Environment Research, 54(5), 487498. doi:10.6115/fer.2016.038

Kim, E. S. (2013). The development of maternal sensitivity improvement parent-education program for enhancing attachment of children with autism. Journal of emotional $\$$ Behavioral disorders, 29(2), 249-276.

Kim, G. H., \& Hong, S. O. (2013). Research trends concerning infants play. Korean Journal of Children's Media, 12(3), 135156.

Kim, H. M., \& Doh, H.-S. (2004). Maternal parenting stress, efficacy, and behavior: Relations to children's social competence. Korean Journal of Child Studies, 25(6), 279-298.

Kim, M. J. (2008). The Development and effects of intervention program for aggressive young children: Focus on social skills training program and parent education (Doctoral dissertation). Retrieved from http://www.riss.kr/link?id=T11204592

Kim, M. J., \& Lee, K. N. (2011). Effects of infants' and toddlers' temperament and mothers' parenting self-efficacy on parenting behavior. Journal of Korean Child Care and Education, 7(4), 253-271

Kim, S. H. (1998). Fathers' involvement in their infant care and the related variables (Master's thesis). Retrieved from http:// www.riss.kr/link?id=T7125085
Kwahk, S.-H., \& Kim, S.-O. (2006). Path model analysis of the maternal childhood attachment, emotions, parenting behaviors and children's behavioral problems. Journal of Korean Home Management Association, 24(6), 95-116.

Kwon, M. K. (2011). Parenting stress and related factors of employed and non-employed mothers with infants. Journal of Korean Child Care and Education, 7(2), 19-41.

Lee, H. M., Park, S. Y., \& Seo, S. J. (2008). The effect of maternal parenting style and sensitivity on infant development. Journal of the Korean Home Economics Association, 46(2), 97-111.

Lee, J.-Y. (2009). The relationships between parenting knowledge and parenting style of mothers with infants: The mediating effect of parenting efficacy. Journal of the Korean Home Economics Association, 47(5), 35-48.

Mun, Y. H. (2013). The influence of mothers' family-of-origin health and self-differentiation on parenting efficacy and parenting attitude (Master's thesis). Retrieved from http://www.riss. $\mathrm{kr} /$ link?id=T13169858

Park, K. J., Park, M. H., \& Chung, Y. S. (2017). What's good to have a sibling?: Quadratic trajectories of fathers' parenting involvement and socio-emotional problem behaviors of children. Journal of Life-span Studies, 7(1), 1-15.

Park, S. Y. (2013). Characteristics of infants and parents and child care type as predictors of infant development (Doctoral dissertation). Retrieved from http://www.riss.kr/ link?id=T13080183

Seo, S. W., \& Lee, D. K. (2014). The effect of father's parenting participation, mother's social support, and mother's psychological characteristics on mother's parenting behavior. Early Childhood Education Research \& Review, 18(2), 135-158.

Yoon, J.-W., \& Cho, H.-H. (2011). Structural modeling of parenting behavior of others with preschool children. Journal of Korean Academy of Child Health Nursing, 17(2), 111-119.

\section{ORCID}

Hye Jin Oh

Hyun-Sim Doh

http://orcid.org/0000-0001-6007-2442

http://orcid.org/0000-0002-7393-4520

Received February 28, 2019

Revision received April 2, 2019

Accepted April 10, 2019 